Gut, 1972, 13, 251-256

\title{
Gastric acid barrier to ingested microorganisms in man: studies in vivo and in vitro
}

\author{
R. A. GIANNELlA, S. A. BROITMAN, AND N. ZAMCHECK ${ }^{1}$ \\ From the Mallory Gastrointestinal Laboratory and the Thorndike Memorial Laboratory, Harvard Medical \\ Unit, Boston City Hospital, the Department of Medicine, Harvard Medical School, and the Departments \\ of Microbiology and Pathology, Boston University School of Medicine, Boston, Mass
}

SUMmaRY Reassessment of the 'gastric bactericidal barrier' to enteric bacteria in man included studies of the bactericidal activity of (1) the normal and achlorhydric stomach in vivo and (2) normal and achlorhydric gastric juice and other media in vitro. Within 30 minutes virtually all bacteria (Serratia marcescens) were eliminated in the normal stomach whereas no reduction occurred in the achlorhydric stomach in one hour. In vitro, identical bactericidal activity was observed at the same $p \mathrm{H}$ (from 2.0 to $7 \cdot 0$ ) in normal gastric juice, achlorhydric gastric juice, aqueous $\mathrm{HCl}$, and nutrient broth. At $p \mathrm{H}$ less than $4 \cdot 0,99.9 \%$ of the bacteria were killed within 30 minutes. The presence of profuse bacterial flora, including coliforms, found in markedly acid-deficient but not in normal stomachs, correlates well with the absence of bactericidal activity. Thus, the 'gastric bactericidal barrier' is primarily $p \mathrm{H}$-hydrochloric acid dependent, with other constituents of gastric juice contributing little, if any, detectable effect on the destruction of microorganisms.

A relationship between gastric acid secretion and bacterial diarrhoeas has been suspected for the past $\mathbf{1 0 0}$ years since enteric bacteria do not survive in an acidic environment (Bartle and Harkins, 1925; Garrod, 1939). Furthermore, gastric bactericidal factors, in addition to acid, have been postulated (Gregersen, 1916; Scheer, 1919; Knott, 1923; Goldsworthy and Florey, 1930; Sebastianelli, 1937; Garrod, 1939; Thompson, 1940; Balazs, 1962). In the latter part of the 19th and early 20th centuries, Hewetson (1904), Knott (1923), Arnold (1927), Camps (1933), Hurst (1934), Garrod (1939), and others (Gregersen, 1916; Scheer, 1919; Bartle and Harkins, 1925; Sebastianelli, 1937) believed that patients with reduced or absent gastric acid secretion were more susceptible to bacterial dysenteries and enunciated the concept of the 'gastric bactericidal barrier' (Hewetson, 1904; Gregersen, 1916; Scheer, 1919; Knott, 1923; Bartle and Harkins, 1925; Arnold, 1927; Camps, 1933; Hurst, 1934; Teale, 1934; Sebastianelli, 1937; Garrod, 1939). Today, despite a century of study, the relationship of gastric acidity to the pathogenesis of enteric infec-

'Please address reprint requests to Dr Norman Zamcheck, Mallory Gastrointestinal Laboratory, Boston City Hospital, Boston, Mass. 02118.

Received for publication 16 December 1971. tions and the particular relevance of gastric anacidity in this regard are still insufficiently appreciated.

It is the purpose of this paper $(a)$ to reassess the bactericidal activity of the normal and achlorhydric stomach and of normal and achlorhydric gastric juice; $(b)$ to enumerate the bacterial flora of the normal and acid-deficient stomach; and $(c)$ to update the clinical relevance of the 'gastric bactericidal barrier' in the light of these findings and those of other workers.

\section{Materials and Methods}

\section{PATIENTS}

Three groups were studied: (1) 10 normal controls (four males and six females) free of gastrointestinal disease, aged 23-82 (mean 49.2); (2) 15 patients (five males and 10 females) with pernicious anaemia in remission, aged 32-82 (mean 62.0); (3) nine subjects (six males and three females) with hypochlorhydria, aged 29-67 (mean 48.8). A diagnosis of pernicious anaemia was made in each by findings of megaloblastic bone marrow, histamine-fast achlorhydria, normal serum folic acid, normal small intestinal radiographs, low serum vitamin $\mathbf{B}_{\mathbf{1 2}}$, abnormal vitamin $B_{12}$ absorption corrected by intrinsic factor, and response to vitamin $\mathbf{B}_{\mathbf{1 2}}$ treatment. Subjects with hypochlorhydria were free 
of gastrointestinal disease and had a basal gastric $p \mathrm{H}$ greater than 6.0 but maximal acid output of 1-10 m-equiv/hour. None of the subjects had received antibiotics for at least two months before our study.

\section{COLLECTION AND PREPARATION OF GASTRIC} JUICES

Gastric juice was collected from each individual during maximal betazole stimulation $(1.75 \mathrm{mg} / \mathrm{kg}$ subcutaneously). Samples were aspirated by continuous hand suction from a nasogastric tube placed under fluoroscopic control. Two basal 15-minute samples were aspirated, betazole was given, and then four additional 15-minute samples were collected. Care was taken to avoid salivary contamination by the patients diligently expectorating saliva and by packing the mouth with dental gauze. Bile- or blood-stained samples were discarded. Individual 15-minute samples were titrated for acidity to $p \mathrm{H} 7.0$ with $0 \cdot 1 N \mathrm{NaOH}$ and the stimulated samples pooled, filtered through loosely packed gauze, and sterilized by filtration though Millipore filters (Millipore Corp, Bedford, Mass) with a pore size of $0.45 \mu$. Sterility was confirmed by aerobic and anaerobic cultures (Giannella, Broitman, and Zamcheck, 1971b).

In preliminary studies, individual gastric juices within each patient group, normal or pernicious anaemia, had identical bactericidal activity at each $p \mathrm{H}$ tested. Therefore, all normochlorhydric and achlorhydric juices were pooled separately.

Each of the pooled normal and pernicious anaemia gastric juices were adjusted to $p \mathrm{H}$ levels 2.0 to 7.0 with either $1.0 \mathrm{~N} \mathrm{NaOH}$ or $1.0 \mathrm{~N} \mathrm{HCl}$ and buffer added to maintain $p \mathrm{H}$. Five $\mathrm{ml}$ of each of the following buffers were added to $50 \mathrm{ml}$ of gastric juice: $p \mathrm{H} 2 \cdot 0, \mathrm{HCl}-\mathrm{KCl}$ buffer $0 \cdot 2 \mathrm{M} ; p \mathrm{H} 3 \cdot 0-5 \cdot 0$, citrate buffer $0 \cdot 1 \mathrm{M} ; p \mathrm{H} 6 \cdot 0-7 \cdot 0$, phosphate buffer $0.2 \mathrm{M}$. The $p \mathrm{H}$ was monitored throughout with a glass electrode. Osmolalities of normal gastric juice varied from $167 \mathrm{mOsm} / \mathrm{kg}$ when adjusted to $p \mathrm{H} 2.0$ up to $392 \mathrm{mOsm} / \mathrm{kg}$ at $p \mathrm{H} \mathrm{7.0}$. Similarly pernicious anaemia gastric juice varied from 117 to 382 , trypticase soy broth from 233 to 400 , and saline from 179 to $397 \mathrm{mOsm} / \mathrm{kg}$. In experiments concerned with the effect of osmolality on bacterial survival, no reduction in bacterial number was noted when saline of various osmolalities $(100-400 \mathrm{mOsm} / \mathrm{kg})$ was tested at various $p \mathrm{H}$ levels. Samples were stored at $-20^{\circ} \mathrm{C}$ until used.

\section{PREPARATION OF ORGANISMS}

Bacteria in stationary growth phase were used since there was no difference in results with either organisms in a stationary or logarithmic growth phase. An 18-hour trypticase soy broth culture was harvested by centrifugation at $3500 \mathrm{rpm}$ for 20 minutes, washed three times in sterile isotonic saline, and suspended in distilled water. The number of organisms was quantitated for each experiment turbidimetrically and by the serial dilution and drop plate technique (Mallmann and Broitman, 1956). The reliability and reproducibility of these methods in our hands have been published previously (Giannella, Broitman, and Zamcheck, 1971a). Organisms used includ ed Escherichia coli, Salmonella typhimurium, Salmonella paratyphi, Salmonella enteritidis, and Serratia marcescens.

In vitro BACTERICIDAL ACTIVITY OF GASTRIC JUICE

To $9.0 \mathrm{ml}$ of each pooled gastric juice at various $p \mathrm{H}$ levels, $1 \mathrm{ml}$ of bacterial suspension $\left(1 \times 10^{\circ}\right.$ organisms) was added and the number surviving enumerated by quantitative culture at intervals up to 120 minutes. As controls, trypticase soy broth and saline, adjusted to the same $p \mathrm{H}$ levels with the same buffer solutions, were also tested. At the conclusion of the experiment, $p \mathrm{H}$ was again tested and did not vary more than $0.2 \mathrm{pH}$ units from the initial $p \mathrm{H}$.

INTRAGASTRIC SURVIVAL OF A TEST ORGANISM Non-pathogenic Serratia marcescens was used as the test organism. Ten $\mathrm{ml}$ of a $3 \%$ polyethylene glycol (PEG) solution containing $1 \times 10^{9}$ viable organisms/ml was instilled into the stomach of three normal subjects and three patients with pernicious anaemia. Polyethylene glycol was used as a non-absorbable marker to correct for dilution of the instilled solution and gastric emptying (Ivey and Schedl, 1970) and in vitro had no effect on bacterial survival or $p \mathrm{H}$ of the sample. Studies were performed in fasting patients in the head-down supine and left lateral decubitus positions to minimize gastric emptying. The bacterial-PEG suspension was instilled into the stomach via a nasogastric tube as a bolus mixed with residual gastric content and a sample aspirated for quantitative bacterial culture (Mallmann and Broitman, 1956), PEG assay (Hyden, 1956), and $p \mathrm{H}$ determination. Samples were withdrawn every 15 minutes for one hour. Cultures to determine the number of surviving bacteria were performed within $\mathbf{3 0}$ minutes of collection. Bile reflux or bloodstaining was not observed and salivary contamination was avoided as described. Numbers of surviving bacteria observed were corrected by PEG retrieval ${ }^{1}$ and

${ }^{1}$ Corrected no. of organisms $=\frac{\text { PEG }(\mathrm{mg} / \mathrm{ml}) \text { out }}{\text { PEG }(\mathrm{mg} / \mathrm{ml}) \text { in }} \times 100 \times$ no. organisms $/ \mathrm{ml}$ in 
results expressed as the corrected number of surviving bacteria per $\mathrm{ml}$ of gastric content.

\section{GASTRIC BACTERIAL FLORA}

Quantitative aerobic and anaerobic bacterial counts were performed on the three patient groups as previously described (Giannella et al, 1971b). Gastric samples were aspirated from fasting subjects via a sterile orogastric tube. The first sample was discarded and the second sample plated within 30 minutes in duplicate on blood agar, trypticase soy agar, as well as on six selective media as described by Schaedler, Dubos, and Costello (1965). Cultures were incubated aerobically for 24 hours and anaerobically for 72 hours. Bacteria were identified by gross colonial characteristics on selective media, microscopic morphology and Gram stains, subculturing, and biochemical tests.

Results are expressed as means $\pm 1 \mathrm{SE}$ and were analysed for statistical significance by the Student $t$ test (Snedecor and Cochran, 1967).

\section{Results}

BACTERICIDAL ACTIVITY OF THE NORMAL AND ACHLORHYDRIC STOMACH

As shown in Fig. 1, when $1 \times 10^{9}$ viable Serratia marcescens were placed into fasting stomachs of three patients with pernicious anaemia (gastric $p \mathrm{H}$ greater than 6.8) no reduction in bacterial number was noted. In contrast, in the normal stomach $(p \mathrm{H}$ less than 3.0) numbers of bacteria were reduced by more than $99 \%$ within 15 minutes and no viable organisms were recoverable after one hour. Since no attempt was made for total PEG recovery and only aliquots of gastric juice were aspirated at each point in time, the data do not permit precise quantitation of gastric dilution and emptying. However, there was an approximately fourfold initial dilution in the normal patients and a threefold dilution in the achlorhydric patients.

BACTERICIDAL ACTIVITY OF GASTRIC JUICE As shown in Fig. 2, gastric juice of both normals and of patients with pernicious anaemia adjusted to $p \mathrm{H} 2.0$ or 3.0 promptly killed more than $99 \%$ of $S$. typhimurium within 15 minutes and more than $99.99 \%$ in 30 minutes. This bactericidal effect was strictly $p \mathrm{H}$ dependent since at $p \mathrm{H} \mathbf{4 . 0}$ or greater, no reduction in bacterial numbers was noted in two hours. Identical bactericidal activity was observed when saline or nutrient broth of similar osmolality and $p \mathrm{H}$ was tested. At no $p \mathrm{H}$ was there any significant difference among the four media. Similar data were obtained for E. coli, Sal. paratyphi, Sal. enteritidis, and Serratia marcescens.

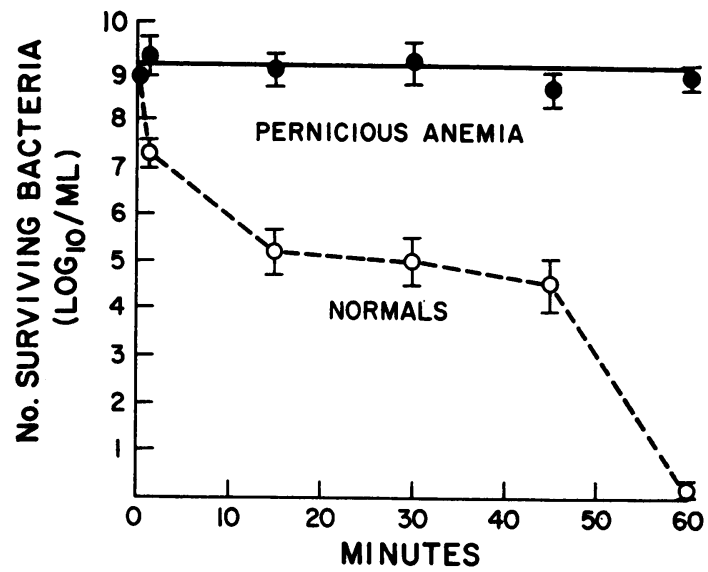

Fig. 1 Intragastric survival of Serratia marcescens in three normal subjects and three patients with pernicious anaemia. Ten $\mathrm{ml}$ of a $3 \%$ PEG suspension of $1 \times 10^{\circ}$ organisms $/ \mathrm{ml}$ was instilled as a bolus. Results are expressed as the corrected number of surviving bacteria per ml of gastric content (see Methods). Each point is the mean $\pm S E$. In patients with pernicious anaemia $\mathrm{pH}$ never fell below 6.8; in normal subjects, $\mathrm{pH}$ was 3.0 or less at each point. Two curves are significantly different at each point in time: one minute $\mathrm{P}=<0.005$, other points $\mathrm{P}=<0.001$.

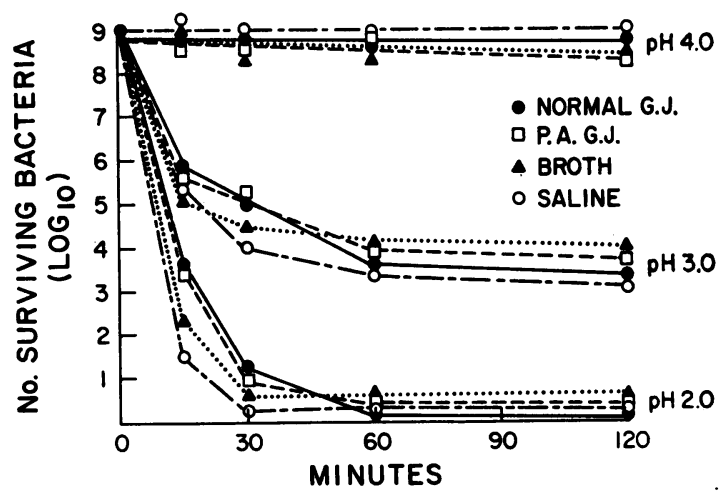

Fig. 2 Comparison of survival of S. typhimurium in normal gastric juice, pernicious anaemia gastric juice, nutrient broth, or saline at various $\mathrm{pH}$ (no. of organisms innoculated $1 \times 10^{\circ} ; \mathrm{pH} 2.0$ maintained with $0.2 \mathrm{M}$ $\mathrm{HCl}-\mathrm{KCl}$ buffer, $\mathrm{pH} 3.0$ and 4.0 with $0.1 \mathrm{M}$ citrate buffer). Each point is the mean of at least six trials. There is no significant difference among the four curves at each pH. G.J. = gastric juice. P.A.G.J. = pernicious anaemia gastric juice. 
To demonstrate that lack of nutrients in gastric juices for bacterial growth did not account for death of bacteria, normal and pernicious anaemia gastric juices were innoculated with $E$. coli or $S$. typhimurium. When the $p \mathrm{H}$ was greater than $5 \cdot 0$, an innoculum of $10^{3}$ organisms multiplied to counts of $10^{8}$ to $10^{9}$ organisms per $\mathrm{ml}$ in 18 hours.

GASTRIC BACTERIAL FLORA OF THE NORMAL AND ACID-DEFICIENT STOMACH

As shown in Table I, the normal fasting stomach contained few organisms, $3 \cdot 4 \pm 0 \cdot 1 \log _{10}$ per $\mathrm{ml}$ of gastric content, equally divided between aerobes and anaerobes. In contrast, either the pernicious anaemia stomach (histamine-fast achlorhydria, $p \mathrm{H}$ greater than 6.8 ) or the hypochlorhydric stomach (fasting $p \mathrm{H}$ greater than 6.0) demonstrated substantial bacterial flora, $7 \cdot 6 \pm 0 \cdot 1$ and $7 \cdot 1 \pm 0 \cdot 2 \log _{10}$ organisms per $\mathrm{ml}$ respectively. In these groups the flora was also equally divided between aerobes and anaerobes. The bacterial counts in both the acid-deficient groups were significantly different from those in the normal group $(P=<0.001)$ but did not differ from each other.

Qualitative differences in gastric bacterial flora between the group of normal subjects and those with either pernicious anaemia or hypochlorhydria were also apparent (Table). While only one of ten $(10 \%)$ normal subjects harboured coliform organisms, 14 of $15(93 \%)$ patients with pernicious anaemia and eight of nine $(89 \%)$ patients with hypochlorhydria harboured coliform organisms in significant concentrations, ie, $4 \cdot 3 \pm 0.5$ and $4 \cdot 7 \pm 0 \cdot 8$ per $\mathrm{ml}$ respectively. The predominant organisms in each of the three groups were aerobic and anaerobic streptococci and aerobic lactobacilli, as well as coliforms in the acid-deficient groups.

\section{Discussion}

Many recent observations support the concept that gastric acidity functions as a 'barrier' to ingested microorganisms. Waddell and Kunz (1956) reported that patients with gastric resection were more susceptible to salmonella enteritis and this was soon confirmed at other hospitals (Nordbring, 1962; Sokol, 1965). Our studies showed that in comparison with normochlorhydric individuals, patients with hypochlorhydria or achlorhydria exibited more severe salmonella enteritis manifested by choleralike diarrhoea with profound loss of fluid and electrolytes (Giannella et al, 1971b and c). Experimental shigellosis in man and cholera in the dog, produced by feeding microorganisms, can be initiated with far fewer organisms if the bacteria are fed with bicarbonate (Sack and Carpenter, 1969; Dupont and Hornick, 1969). Recently, preliminary evidence suggests that hypochlorhydric and achlorhydric individuals are more susceptible to cholera (Sack, Hennessey, Mitra, and Pierce, 1970).

Attempts to define the components of the 'gastric barrier' to microorganisms have been contradictory. The older literature has been comprehensively reviewed by Bartle and Harkins (1925) and by Garrod (1939). Knott (1923) and others (Arnold, 1927; Camps, 1933; Hurst, 1934; Teale, 1934), in studies in vitro, concluded that the free acid content of gastric juice was the sole antibacterial factor. Garrod (1939) and others (Gregersen, 1916; Scheer, 1919), however, using similar methods, concluded

\begin{tabular}{|c|c|c|c|c|c|c|}
\hline & \multicolumn{2}{|c|}{$\begin{array}{ll}\text { Normals }^{2} & \\
& (10)^{4}\end{array}$} & \multicolumn{2}{|c|}{$\begin{array}{c}\text { Hypochlorhydria } \\
\text { (9) }\end{array}$} & \multicolumn{2}{|c|}{$\begin{array}{c}\text { Pernicious Anaemia } \\
\text { (15) }\end{array}$} \\
\hline & $M e a n \pm S E$ & Percentage $^{5}$ & $M e a n \pm S E$ & Percentage & $M e a n \pm S E$ & Percentage \\
\hline $\begin{array}{l}\text { Coliforms }^{6} \\
\text { Staphylococci } \\
\text { Streptococci } \\
\text { Aerobic lactobacilli } \\
\text { Bifidobacteria } \\
\text { Anaerobic streptococci } \\
\text { Bacteroides } \\
\text { Clostridia } \\
\text { Total organisms } \\
\text { Total anaerobes } \\
\text { Total aerobes }\end{array}$ & $\begin{array}{l}0 \cdot 3 \pm 0 \cdot 3 \\
1 \cdot 2 \pm 0 \cdot 4 \\
2 \cdot 6 \pm 0 \cdot 3 \\
1 \cdot 9 \pm 0 \cdot 5 \\
1 \cdot 0 \pm 0 \cdot 6 \\
2 \cdot 7 \pm 0 \cdot 3 \\
- \\
- \\
3 \cdot 4 \pm 0 \cdot 1 \\
3 \cdot 0 \pm 0 \cdot 2 \\
3 \cdot 2 \pm 0 \cdot 1\end{array}$ & $\begin{array}{l}10 \\
50 \\
90 \\
70 \\
30 \\
90 \\
- \\
-\end{array}$ & $\begin{array}{l}4 \cdot 7 \pm 0 \cdot 8 \\
1 \cdot 2 \pm 0 \cdot 6 \\
4 \cdot 2 \pm 0 \cdot 6 \\
4 \cdot 3 \pm 1 \cdot 1 \\
2 \cdot 3 \pm 1 \cdot 2 \\
6 \cdot 5 \pm 0 \cdot 2 \\
- \\
- \\
7 \cdot 1 \pm 0 \cdot 2 \\
6 \cdot 9 \pm 0 \cdot 2 \\
6 \cdot 2 \pm 0 \cdot 4\end{array}$ & $\begin{array}{r}89 \\
33 \\
89 \\
67 \\
33 \\
100 \\
- \\
-\end{array}$ & $\begin{array}{l}4 \cdot 3 \pm 0.5 \\
3 \cdot 3 \pm 1 \cdot 0 \\
6 \cdot 1 \pm 0 \cdot 4 \\
2 \cdot 8 \pm 0.9 \\
0 \cdot 9 \pm 0.6 \\
7 \cdot 3 \pm 0 \cdot 2 \\
1 \cdot 3 \pm 0.7 \\
-7 \cdot 6 \pm 0 \cdot 1 \\
7 \cdot 3 \pm 0 \cdot 1 \\
7 \cdot 0 \pm 0.3\end{array}$ & $\begin{array}{r}93 \\
47 \\
100 \\
40 \\
13 \\
100 \\
20 \\
-\end{array}$ \\
\hline
\end{tabular}

Table Gastric bacterial flora of fasting subjects ${ }^{1}$

${ }^{1}$ Expressed as mean $\pm 1 \mathrm{SE} \log _{10} / \mathrm{ml}$ fasting gastric content

'Basal gastric $p \mathrm{H} 3.0$ or less in each subject

'Basal $p \mathrm{H}>6.0$

-Number of subjects studied

'Percentage of subjects from whom organism was isolated

-No difference between pernicious anaemia and hypochlorhydric groups but each significantly greater than number of bacteria in normal group $(P=<0.001)$

'Significantly greater in pernicious anaemia group than in normals $(P=<0.001)$ 
that gastric juice was more bactericidal than hydrochloric acid of equivalent acidity. Sebastianelli (1937) showed that neutralized normal gastric juice retained its bactericidal activity.

In vivo studies have been few. Hewetson in 1904 introduced peptone broth cultures of various bacteria into his own as well as into the stomachs of patients with gastrotomies and concluded that pyogenic cocci were killed in 30 to 45 minutes and bacilli in 60 to 90 minutes. Hood and Arnold (1937) measured the disappearance of Serratia marcescens from the stomachs of achlorhydric individuals in one to three hours. Dack and Petran (1934) instilled the same organism into the stomach of a single monkey and noted no death of organisms in five hours. However, the $p \mathrm{H}$ of the gastric content remained above $4 \cdot 5$. This reference has been erroneously cited in the past as evidence against the existence of a 'gastric barrier'. The lack of controls for the effects of gastric dilution and gastric emptying as well as the use of diseased or surgically altered stomachs have limited interpretation of these studies. On the other hand, evidence supporting the bactericidal role of the intact stomach in dogs was reported by Arnold and Brody (1926). They observed that bacteria introduced alone into the empty stomach or in an acid-buffered aqueous solution seldom reached the caecum. However, bacteria introduced with alkaline-buffered milk reached the caecum in large numbers.

The present study demonstrates strict $p \mathrm{H}$ dependence of the bactericidal activity of gastric juice, ie, prompt killing of bacteria at $p \mathrm{H}$ less than 4.0. When the $p \mathrm{H}$ of normal gastric juice was raised to greater than 4.0 , no bactericidal activity was detected. Pernicious anaemia gastric juice, likewise, demonstrated no bactericidal activity unless acidified to $p \mathrm{H}$ below 4.0 , where it behaved identically to normal gastric juice. Furthermore, the observations that saline and nutrient broth had bactericidal activity identical to that of gastric juice at comparable $p \mathrm{H}$ levels do not support the presence of other significant antibacterial factors. Nutrient lack in gastric juice as a factor contributing to death of bacteria was also excluded.

Our studies in vivo of intragastric bactericidal activity demonstrated prompt reduction in the number of bacteria in the normal stomach but no reduction in the achlorhydric stomach. Hence, the lack of detectable antibacterial activity in the achlorhydric stomach would appear to account for the profuse gastric bacterial flora found in these patients. With an increase in $p \mathrm{H}$, as in the hypochlorhydric and achlorhydric stomachs, the total number of organisms per $\mathrm{ml}$ of gastric content increases, in agreement with previous findings (Franklin and
Skoryna, 1966; Gray and Shiner, 1967; Drasar, Shiner, and McLeod, 1969). It has been thought that the high $p \mathrm{H}$ of the acid-deficient stomach permits oral and ingested bacteria to survive and multiply (Franklin and Skoryna, 1966; Gorbach, Plaut, Nahas, Weinstein, Spanknebel, and Levitan, 1967; Drasar et al, 1969). Drasar et al (1969) showed that ingested bacteria reside only transiently in the normal stomach. Our findings of a substantial coliform flora in 89 to $93 \%$ of acid-deficient stomachs and the infrequency of bacteroides sp. as a component of the gastric flora, is also in accord with recent reports (Levanto, 1954; Dellipiani and Girdwood, 1964; Gray and Shiner, 1967; Gorbach et al, 1967; Drasar et al, 1969).

Our studies, in sum, clearly support the concept of a 'gastric barrier' to ingested bacteria. It appears to be primarily a $p \mathrm{H}$-hydrochloric-acid-dependent mechanism. The contribution to the gastric defence of other constituents of gastric juice suggested over the years, including organic acids (Knott, 1923), mucus (Goldsworthy and Florey, 1930), lysozyme (Thompson, 1940), and antibodies (Balazs, 1962), however, is unconvincing. In addition to the acid secretory capacity of the stomach, a complex set of interactions influences and modifies the bactericidal activity of the stomach including $(a)$ the number of bacteria ingested, $(b)$ the vehicle in which they are ingested, $(c)$ physical protection of bacteria by food, $(d)$ buffering of gastric content, and $(e)$ the rate of gastric emptying. Little information is available concerning the relative importance of these latter factors to the 'gastric bactericidal barrier'.

The weight of evidence supports a role of reduced gastric acid-imposed by a disease process or the result of gastric surgery-in contributing to the frequency and severity of bacterial infections of the intestine. A prospective study of the gastric secretory status of patients residing in areas of endemic infectious diarrhoeas may provide further support for the clinical applicability of this concept.

The authors are indebted to Dr Helene Loux for her assistance with the patients with pernicious anaemia, to $\mathrm{Mr}$ Richard McCabe for technical assistance, and to Dr Edward Kass for his helpful suggestions.

This investigation was supported by grants from the National Cancer Institute CA 04486 and CA 02090, the National Institute of Arthritis and Metabolic Disease TI AM 5320, and the National Institute of Allergy and Infectious Diseases AI 07913, National Institutes of Health, Bethesda, Maryland.

References

Arnold, L. (1927). Host susceptibility to typhoid, dysentery, food poisoning and diarrhea. J. Amer. med. Ass., 89, 789-791. 
Arnold, L., and Brody, L. (1926). The gastro-duodenal bactericidal mechanism. Amer. J. Hyg., 6, 672-683.

Balazs, V. (1962). Studies on the antibody content of anacid gastric juices. Experienta (Basel), 18, 72-73.

Bartle, H. J., and Harkins, M. J. (1925). The gastric secretion: its bactericidal value to man. Amer. J. med. Sci., 169, 373-388.

Camps, F. E. (1933). Achlorhydria and dysentery: observations on test-meals of 100 post-dysenteric cases. Guy's Hosp. Rep., 83, 123-128.

Dack, G. M., and Petran, E. (1934). Bacterial activity in different levels of the intestine. J. infect. Dis., 54, 204-220.

Dellipiani, A. W., and Girdwood, R. H. (1964). Bacterial changes in the small intestine in malabsorptive states and in pernicious anaemia. Clin. Sci., 26, 359-374.

Drasar, B. S., Shiner, M., and McLeod, G. M. (1969). Studies on the intestinal flora. I. The bacterial flora of the gastrointestinal tract in healthy and achlorhydric persons. Gastroenterology, 56, 71-79.

Dupont, H. L., and Hornick, R. B. (1969). Diarrheal diseases. D.M., July, 3-40.

Franklin, M. A., and Skoryna, S. C. (1966). Studies on natural gastric flora. I. Bacterial flora of fasting human subjects. Canad. med. Ass. J., 95, 1349-1355.

Garrod, L. P. (1939). A study of the bactericidal power of hydrochloric acid and of gastric juice. St Bart. Hosp. Rep., 72, 145-167.

Giannella, R. A., Broitman, S. A., and Zamcheck, N. (1971a). Vitamin $B_{12}$ uptake by intestinal microorganisms: mechanism and relevance to syndromes of intestinal bacterial overgrowth. J. clin. Invest., 50, 1100-1107.

Giannella, R. A., Broitman, S. A., and Zamcheck, N. (1971b). Salmonella enteritis. I. Role of reduced gastric secretion in pathogenesis. Amer. J. dig. Dis., 26, 1000-1006.

Giannella, R.A., Broitman, S.A., and Zamcheck, N. (1971c). Salmonella enteritis. II. Fulminant diarrhea in and effects on the small intestine. Amer. J. dig. Dis., 16, 1007-1013.

Goldsworthy, N. E., and Florey, H.(1930). Some properties of mucus with special reference to its antibacterial functions. Brit. $J$. exp. Path., 11, 192-208.

Gorbach, S. L., Plaut, A. G., Nahas, L., Weinstein, L., Spanknebel, G., and Levitan, R. (1967). Studies of intestinal microflora. II. Microorganisms of the small intestine and their relations to oral and fecal flora. Gastroenterology, 53, 856-867.

Gray, J. D. A., and Shiner, M. (1967). Influence of gastric $p H$ on gastric and jejunal flora. Gut, 8, 574-581.

Gregersen, J. P. (1916). Untersuchungen über die antiseptische Wirkung des Magensaftes. Zbl. Bakt. I. Abt. Orig., 77, 353-361.

Hewetson, J. T. (1904). The bacteriology of certain parts of the human alimentary canal and the inflammatory processes arising therefrom. Brit. med. J., 2, 1457-1460.

Hood, M., and Arnold, L. (1937). The relationship between oral and gastric bacterial flora. Amer. J. dig. Dis., 4, 40-43.

Hurst, A. F. (1934). The clinical importance of achlorhydria. Brit. med., J., 2, 665-669.

Hyden, S. (1956). A turbidimetric method for the determination of higher polyethylene glycols in biological materials. $K$. LantbrHögsk. Annlr., 22, 139-143.

Ivey, K. J., and Schedl, H. P. (1970). Gastric nonabsorbable indicators for studies in man. Gastroenterology, 59, 234-239.

Knott, F. A. (1923). The gastric germicidal barrier. Guy's Hosp. Rep. 73, 429-437.

Levanto, A.(1954). Astudy of gastric Escherichia strains with reference to pernicious anenia. Ann. Med. intern. Fenn., 43, Suppl. 20.

Mallmann, W. L., and Broitman, S. A. (1956). A surface plating technic for determining bacterial population of milk. Amer. J. pub. Hlth, 46, 1018-1020.

Nordbring, F. (1962). Contraction of salmonella gastroenteritis following previous operation on the stomach. Acta med. scand., 171, 783-790.

Sack, G. H., Jr., Hennessey, K. N., Mitra, R. C., and Pierce, N. F. (1970). Gastric acidity in cholera. (Abstr.) Clin. Res., 18, 682.

Sack, R. B., and Carpenter, C. C. J. (1969). Experimental canine cholera. I. Development of the model. J. infect. Dis., 119, 138-149.

Schaedler, R. W., Dubos, R., and Costello, R. (1965). The development of the bacterial flora in the gastrointestinal tract of mice. J. exp. Med., 122, 59-66.

Scheer, K. (1919). Ueber die keimtötende Wirkung des Magensaftes auf die Bazillen der Typhus-, Koli-, und der Ruhrgruppe. Arch. Hyg. (Berl.), 88, 130-138.

Sebastianelli, A. (1937). Sul potere battericida del succo gastrico. Policlinico, Sez. prat., 44, 1593-1602.

Snedecor, G. W., and Cochran, W. G. (1967). Statistical Methods, p. 59. Iowa State University Press, Ames, Iowa.

Sokol, E. M. (1965). Salmonella derby infections after gastrointestinal surgery. J. Mt Sinai Hosp., 32, 36-41.

Teale, F. H. (1934). Experiments on the portal of entry of bacteria and the production of intestinal infection. J. Path. Bact., 39, 391-407.

Thompson, R. (1940). Lysozyme and its relation to the antibacterial properties of various tissues and secretions. Arch. Path., 30, 1096-1134.

Waddell, W. R., and Kunz, L. J. (1956). Association of salmonella enteritis with operation on the stomach. New Engl. J. Med., 255, 555-559. 